\title{
Rift Valley fever - a threat for Europe?
}

V Chevalier (veronique.chevalier@cirad.fr) ${ }^{1}$, M Pépin $^{2}$, L Plée 3 , R Lancelot ${ }^{4}$

1. Centre International de Recherche Agronomique pour le Développement (CIRAD, International Centre of Agricultural Research for Development), Unit for animal and integrated risk management (UR AGIRs), Montpellier, France

2. Agence française pour la sécurité sanitaire des aliments (AFSSA, French Agency for Food Safety), Lyon, France

3. Agence française pour la sécurité sanitaire des aliments (AFSSA, French Agency for Food Safety), Unit for the evaluation of risks associated with food and animal health, Maisons-Alfort, France

4. Centre International de Recherche Agronomique pour le Développement (CIRAD, International Centre of Agricultural Research for Development), Unit for the control of exotic and emerging animal diseases (UMR CMAEE), Montpellier, France

Citation style for this article: Chevalier V, Pépin M, Plée L, Lancelot R. Rift Valley fever - a threat for Europe?. Euro Surveill. 2010;15(10):pii=19506. Available online: http://www.eurosurveillance.org/ViewArticle.aspx?Articleld $=19506$

This article has been published on 11 March 2010

Rift Valley fever (RVF) is a severe mosquito-borne disease affecting humans and domestic ruminants, caused by a Phlebovirus (Bunyaviridae). It is widespread in Africa and has recently spread to Yemen and Saudi Arabia. RVF epidemics are more and more frequent in Africa and the Middle East, probably in relation with climatic changes (episodes of heavy rainfall in eastern and southern Africa), as well as intensified livestock trade. The probability of introduction and large-scale spread of RVF in Europe is very low, but localised RVF outbreaks may occur in humid areas with a large population of ruminants. Should this happen, human cases would probably occur in exposed individuals: farmers, veterinarians, slaughterhouse employees etc. Surveillance and diagnostic methods are available, but control tools are limited: vector control is difficult to implement, and vaccines are only available for ruminants, with either a limited efficacy (inactivated vaccines) or a residual pathogenic effect. The best strategy to protect Europe and the rest of the world against RVF is to develop more efficient surveillance and control tools and to implement coordinated regional monitoring and control programmes.

\section{Relevance of Rift Valley fever to public health in the European Union}

Rift Valley fever (RVF) is a zoonotic disease of domestic ruminants and humans caused by an arbovirus belonging to the Phlebovirus genus (family Bunyaviridae). It causes high mortality rates in newborn ruminants, especially sheep and goats, and abortion in pregnant animals. Human infection by the RVF virus (RVFV) may result from mosquito bites, exposure to body fluids of livestock or to carcasses and organs during necropsy, slaughtering, and butchering [1].

The public health impact of RVF can be severe. In Egypt in 1976, 200,000 people were infected and 600 fatal cases officially reported, among others in the River Nile delta [2]. Over 200 human deaths were reported in Mauritania in 1987 [3]. In 2007-2008, 738 human cases were officially reported in Sudan, including 230 deaths
[4]. It is likely that the number of cases was underreported because RVF mostly affects rural populations living far from public health facilities. The occurrence of RVF in northern Egypt is evidence that RVF may occur in Mediterranean countries, thus directly threatening Europe. In the Indian Ocean, RVF has been introduced in the French island of Mayotte, with several clinical cases reported in humans [5]

\section{Transmission, epidemiology and clinical symptoms}

The RVFV transmission cycle involves ruminants and mosquitoes. Host sensitivity depends on age and animal species [6] (Table 1). Humans are dead-end hosts. The epidemiological cycle is made more complex by direct transmission from infected ruminants to healthy ruminants or humans, by transovarian transmission in some mosquito species, and by a large number of potential vectors with different bio-ecology [6]. The existence of wild reservoir hosts has not been clearly demonstrated to date (Figure 1).

\section{Transmission mechanisms}

The bite of infected mosquitoes is the main transmission mechanism of RVF in ruminants during inter-epizootic periods. More than 30 mosquito species were found to be infected by RVFV $[6,7]$ (Table 2), belonging to seven genera of which Aedes and Culex are considered as the most important from the point of view of vector competence (other genera are Anopheles, Coquillettidia, Eretmapodite, Mansonia and Ochlerotatus).

In mosquitoes, transovarian RVFV transmission has been observed in Aedes mcintoshi. It appears to be a likely phenomenon in several other species, including the widespread Ae. vexans species complex. In some of these Aedes species, infected, diapaused eggs may survive in dried mud during inter-epizootic and/or dry/ cold periods [8] and hatch infected imagos.

Ruminant-to-human transmission is the main infection route for humans, although they can also be infected 
by mosquito bites [9]. Body fluids such as the blood (during slaughtering and butchering), foetal membranes and amniotic fluid of viraemic ruminants are highly infective for humans. Fresh and raw meat may be a source of infection for humans, but the virus is destroyed rapidly during meat maturation. Empirical field observations indicate that ruminants can also become infected by contact with material containing virus (e.g. fetus and fetal membranes after abortion), however, this route of transmission has not yet been confirmed [10].

\section{TABLE 1}

Species susceptibility and sensibility to the Rift Valley fever virus

\begin{tabular}{|c|c|c|c|c|}
\hline Mortality $\mathbf{7 0 \%}$ & Mortality $\mathbf{1 0 - 7 0 \%}$ & $\begin{array}{c}\text { Severe disease with low } \\
\text { fatality rate (\$10\%) }\end{array}$ & Antibody production & Not susceptible \\
\hline Lamb & Sheep & Human & Camel & Bird \\
\hline Kid & Calf & Cattle & Horse & Reptile \\
\hline Puppy & Some rodents & Goat & Cat & \\
\hline Kitten & & African Buffalo & Dog & \\
\hline Mouse & & Asian Buffalo & Swine & \\
\hline Rat & & Monkey & Donkey & \\
\hline & & & Rabbit & \\
\hline
\end{tabular}

Reproduced from Lefèvre et al. [5] with permission from the publisher (Lavoisier, France)

\section{FIGURE 1}

Epidemiological cycle of Rift Valley fever

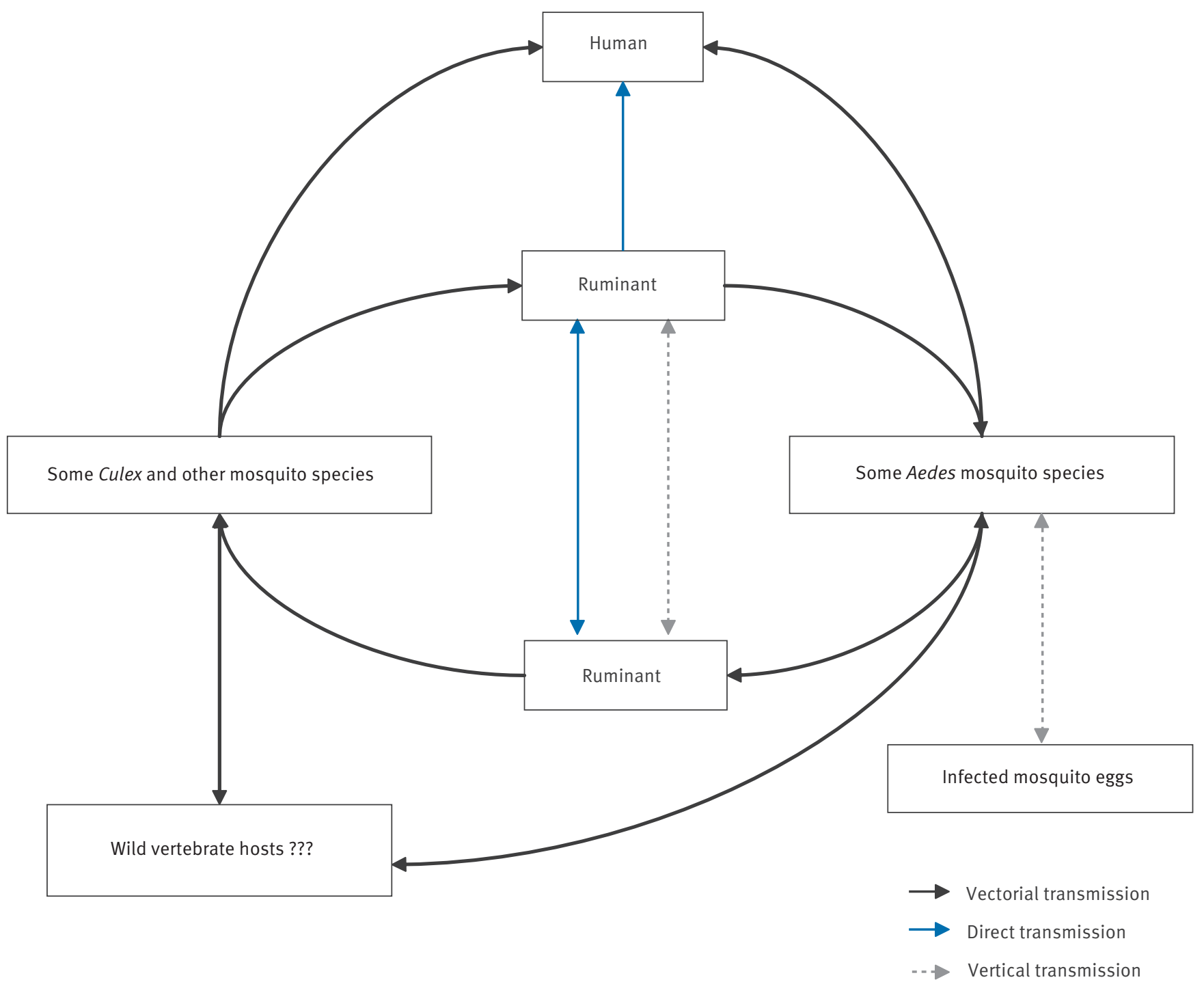


TABLE 2

Arthropods naturally infected by Rift Valley fever virus

\begin{tabular}{|c|c|c|}
\hline Genus & Species & Country (year) \\
\hline \multirow[t]{8}{*}{ Aedes (Aedimorphus) } & cumminsii & Kenya (1981-1984) \\
\hline & & Burkina Faso (1983) \\
\hline & dalzieli & Senegal $(1974,1983)$ \\
\hline & dentatus & Zimbabwe (1969) \\
\hline & durbanensis & Kenya (1937) \\
\hline & ochraceus & Senegal (1993) \\
\hline & tarsalis & Uganda (1944) \\
\hline & vexans arabiensis & $\begin{array}{c}\text { Senegal (1993) } \\
\text { Saudi Arabia (2000) }\end{array}$ \\
\hline \multirow[t]{3}{*}{ Aedes (Neomelaniconion) } & circumluteolus & $\begin{array}{c}\text { Uganda }(1955) \\
\text { South Africa }(1955,1981)\end{array}$ \\
\hline & mcintoshi & $\begin{array}{c}\text { Zimbabwe (1969) } \\
\text { South Africa (1974-1975) } \\
\text { Kenya (1981-1984) } \\
\end{array}$ \\
\hline & palpalis & Central African Republic (1969) \\
\hline \multirow[t]{3}{*}{ Ochlerotatus (Ochlerotatus) } & caballus & South Africa (1953) \\
\hline & caspius & Suspected, Egypt (1993) \\
\hline & juppi & South Africa (1974-1975) \\
\hline \multirow[t]{2}{*}{ Aedes (Stegomya) } & africanus & Uganda (1956) \\
\hline & demeilloni & Uganda (1944) \\
\hline Aedes (Diceromya) & furcifer group & Burkina Faso (1983) \\
\hline \multirow[t]{2}{*}{ Anopheles (Anopheles) } & coustani & $\begin{array}{l}\text { Zimbabwe (1969) } \\
\text { Madagascar (1979) }\end{array}$ \\
\hline & fuscicolor & Madagascar (1979) \\
\hline \multirow[t]{4}{*}{ Anopheles (Cellia) } & chrityi & Kenya (1981-1984) \\
\hline & cinereus & South Africa (1974-1975) \\
\hline & pauliani & Madagascar (1979) \\
\hline & pharoensis & Kenya (1981-1984) \\
\hline \multirow[t]{9}{*}{ Culex (Culex) } & spp. & Madagascar (1979) \\
\hline & antennatus & $\begin{array}{l}\text { Nigeria(1967-1970) } \\
\text { Kenya (1981-1984) }\end{array}$ \\
\hline & neavi & South Africa (1981) \\
\hline & pipiens & Egypt (1977) \\
\hline & poicilipes & Senegal $(1998,2003)$ \\
\hline & theileri & $\begin{array}{l}\text { South Africa (1970) } \\
\text { Zimbabwe (1969) }\end{array}$ \\
\hline & tritaeniorhynchus & Saudi Arabia (2000) \\
\hline & vansomereni & Kenya (1981-1984) \\
\hline & zombaensis & $\begin{array}{c}\text { South Africa }(1981) \\
\text { Kenya }(1981-1984,1989)\end{array}$ \\
\hline Culex (Eumelanomya) & rubinotus & Kenya (1981-1984) \\
\hline \multirow[t]{2}{*}{ Eretmapodites } & chrysogaster & Uganda (1944) \\
\hline & quinquevittatus & $\begin{array}{l}\text { South Africa (1971) } \\
\text { Kenya (1981-1984) }\end{array}$ \\
\hline \multirow[t]{2}{*}{ Coquillettidia } & fuscopennata & Uganda (1959) \\
\hline & grandidieri & Madagascar (1979) \\
\hline \multirow[t]{2}{*}{ Mansonia (Mansoniodes) } & africana & $\begin{array}{c}\text { Uganda }(1959,1968) \\
\text { Central African Republic (1969) } \\
\text { Kenya (1989) }\end{array}$ \\
\hline & uniformis & $\begin{array}{c}\text { Uganda (1959) } \\
\text { Madagascar (1979) }\end{array}$ \\
\hline Other diptera & Culicoides spp. & Nigeria (1967) \\
\hline
\end{tabular}

Adapted from [1]. 
Direct human-to-human transmission has not been reported, and RVF is not considered to be a nosocomial disease. Transplacental RVFV transmission may occur in vertebrates, including humans. It results in abortion and high newborn mortality rates [11].

Rodents may be infected during epizootic periods [1215] but their epidemiological role in virus transmission and maintenance is not clear. Bat species also have been suspected [16]. Finally, wild ruminants may play a role in the epidemiology of RVF in areas where their population density is high [17].

\section{Clinical features}

Animals

Clinical manifestations vary depending on age and animal species. In sheep, a fever of up to $41-42^{\circ} \mathrm{C}$ is observed after a short incubation period. Newborn lambs (and sometimes kids) usually die within 36 to 40 hours after the onset of symptoms, with mortality rates sometimes reaching $95 \%$. Older animals (from two weeks to three months-old) either die or develop only a mild infection. In pregnant ewes, abortions are frequent, ranging from $5 \%$ to $100 \%$. Twenty per cent of the aborting ewes die. Vomiting may be the only clinical sign presented by adult sheep and lambs older than three months. However, these animals may experience fever with depression, haemorrhagic diarrhoea, bloodstained muco-purulent nasal discharge, and icterus. Case-fatality rates vary between $20 \%$ and $30 \%$. Adult goats develop a mild form of the disease, but abortions are frequent (80\%). Mortality rates are generally low [10]. Calves often develop acute illness, with fever, fetid diarrhoea, and dyspnoea. Mortality rates may vary from $10 \%$ to $70 \%$. Abortion is often the only clinical sign and mortality rates are low (10-15\%).

\section{Humans}

In most cases, human infections remain unapparent, or with mild, influenza-like symptoms. However, infected people may experience an undifferentiated, severe, influenza-like syndrome and hepatitis with vomiting and diarrhoea. Complications may occur. Severe forms are manifested in three different clinical syndromes. The most frequent one is a maculo-retinitis, with blurred vision and a loss of visual acuity due to retinal haemorrhage and macular oedema. Encephalitis may also occur, accompanied by confusion and coma. This form is rarely fatal but permanent sequelae are encountered. The third and most severe form is a haemorrhagic fever, with hepatitis, thrombocytopenia, icterus, and multiple haemorrhages. This form is often fatal $[10,18,19]$. Human case-fatality rates have been lower than $1 \%$ in the past, however, an increase has been reported since 1970 [19]. In the RVF epidemic in Saudi Arabia in the year 2000 , the fatality rate reached $14 \%$ [20].

\section{Diagnostic methods}

RVFV presents a high biohazard for livestock farmers, veterinarians, butchers, slaughterhouse employees, and laboratory staff handling infected biological samples. International public health agencies have set a bio-safety level (BSL) of $\mathrm{BSL}_{3}$ for facilities in Europe handling the virus and of BSL4 for facilities in the United States (US).

Appropriate diagnostic samples are peripheral blood collected on EDTA, plasma or serum of infected animals or patients, and the liver, brain, spleen or lymph nodes of dead animals. When samples can be conveyed rapidly to a diagnostic laboratory ( $\$ 48$ hours), they should be stored at a temperature below $+4{ }^{\circ} \mathrm{C}$. When this is not the case, samples should be frozen at $-20{ }^{\circ} \mathrm{C}$ (or below). Small fragments of organs may be stored in a $10-20 \%$ glycerol solution

Virus isolation can be performed in suckling or weaned mice by intracerebral or intraperitoneal inoculation or in a variety of cell cultures including Vero, BHK21, or mosquito line cells. RVFV can be identified in cell cultures by immunofluorescence, virus neutralisation test, reverse transcriptase polymerase chain reaction (RT-PCR), and/or genome sequencing. Virus isolation is the gold standard for RVF diagnosis. However, its sensitivity is rather low: RVFV isolation is not easy to achieve. Alternatively, the detection of RVFV ribonucleic acid (RNA) can be done using RT-PCR performed on RNA extracted directly from biological samples [21]. Results are available within a few hours, which makes RT-PCR the priority test when a case of RVF is suspected.

Serological tests to detect antibodies against RVFV include the virus neutralisation test (VNT), and enzymelinked immunosorbent assays (ELISA). VNT is very specific, cross reactions with other Phleboviruses being limited [22;23]. It is the gold standard serological test. However, it is costly, time consuming, and requires a $\mathrm{BSL} 3$ or 4 laboratory.

(Indirect) immunoglobulin (Ig) detection ELISAs are quick, sensitive and specific. They are progressively replacing VNT [24]. A competition ELISA (cELISA) is also commercially available to detect IgG and IgM. It allows serological diagnosis in ruminants and humans. At the earliest, it can detect antibodies as soon as four days following infection or vaccination in animals reacting very early, and eight days post-vaccination for $100 \%$ of animals [25]. More recently, another indirect ELISA based on a recombinant RVFV nucleoprotein has been developed. Its sensitivity is $98.7 \%$ and specificity $99.4 \%$ [26-28].

The cELISA has been evaluated with human and animal sera collected in Africa, and also with sera from French livestock (cattle, sheep and goats) to check their specificity with European ruminant breeds which turned out to be excellent with a predictive negative value of 
$100 \%(n=502), 95 \%$ confidence interval: 99.3 to $100 \%$ [29].

\section{Treatments}

There is no specific treatment for either humans or animals.

\section{Prevention}

Vaccines

A human vaccine (inactivated with beta-propiolactone) has been produced in the US and was used to protect laboratory staff and military troops. However, its production has been stopped [30].

Given that domestic ruminants are involved in the epidemiological cycle and that humans mostly become infected after contact with viraemic animals, the vaccination of ruminants is the method of choice to prevent human disease. Both live and inactivated vaccines are available for livestock.

The Smithburn vaccine is a live attenuated vaccine. It is inexpensive to prepare and immunogenic for sheep, goats, and cattle. It protects these species against abortion caused by a wild RVFV, and post-vaccinal immunity is life long. However, it has a residual pathogenic effect and may induce foetal abnormalities and/or abortion in ruminants. It is also pathogenic for humans (febrile syndrome). Despite these drawbacks, it is recommended by the Food and Agriculture Organization of the United Nations (FAO) [31] and remains the most widely used vaccine against RVF in Africa.

The inactivated RVF vaccine provides a lower level of protection and its production is more expensive. Moreover, it requires at least two inoculations and frequent booster shots to induce the desired level of protection, rendering it inappropriate in countries where large portions of ruminant herds are nomadic. However, it was used by the Israeli veterinary services to prevent RVF introduction to Israel after the 19771978 epidemic in Egypt [32], as well as by the Egyptian veterinary services to prevent re-introduction of RVF from Sudan after an epidemic hit that country in 2007.

Other candidate vaccines are being evaluated such as the so-called "clone 13" which is an attenuated strain of RVFV that was isolated from a moderately ill patient in the Central African Republic [33]. This vaccine induces neutralising antibodies against RVFV. New-generation vaccines are also under study: recombinant vaccines using a poxvirus or an Alphavirus-based vector [34,35] and DNA vaccines $\left[34^{*}, 36^{*}\right.$. However, these vaccines are still in the preliminary stages of development.

Smithburn and inactivated vaccines are produced and commercially available in Egypt, South Africa, and Kenya. There is no Community pharmaceutical legislation prohibiting companies from producing RVF vaccines on EU territory and there is no obligation to notify such production to the European Commission.
Moreover, quoting Council Directive 2001/82/EC (EC 2001b), "in the event of serious epizootic diseases, Member States may provisionally allow the use of immunological veterinary medicinal products without a marketing authorisation, in the absence of a suitable medicinal product and after informing the Commission of the detailed conditions of use (article 8)" [37*].

\section{Insecticide treatments}

Larvicide treatments may provide a control alternative where mosquito breeding sites are well identified and cover limited surface areas. Both Methoprene, a hormonal larval growth inhibitor, and Bacillus thuringiensis israeliensis (BTI) preparations, a microbial larvicide, are commercially available and can be used successfully to treat temporary ponds and watering places where mosquitoes proliferate. Adulticide treatments (e.g. using pyrethroids) are expensive and difficult to implement. Moreover, because this usually involves treating large areas, the environmental and ecological consequences may be important.

\section{Other measures}

Preventive measures should also include restrictions on animal movements, the avoidance or control of the slaughter and butchering of ruminants, the use of insect repellents and bed nets during outbreaks, information campaigns, and increased and targeted surveillance of animals, humans and vectors.

\section{Current geographical distribution}

RVF is either enzootic, or is reported in most sub-Saharan African countries, Egypt and Madagascar (Figure 2).

During the first large epidemic, reported in Egypt in 1977-1978, over 600 people died of RVF [39]. The epidemic reached the Mediterranean shore (Nile delta) but did not spread to neighbouring countries. In September 2000, RVF was detected for the first time outside of the African continent in Saudi Arabia and Yemen, and led to human deaths and major livestock losses [40]. By the end of 2006, the disease had re-emerged in Kenya [41], followed by Tanzania and Somalia [42]. Another large epidemic hit the Sudan in 2007 in the Nile Valley around Khartoum [4]. In May 2007, RVF was diagnosed on the French island of Mayotte in a young boy who had been evacuated from Anjouan, one of the other islands of the Comoros archipelago. The RVFV was probably introduced there by the trade of live ruminants imported from Kenya or Tanzania during the 2006-2007 epidemics. Studies conducted after this first human case was reported have shown that $10 \%$ of cattle had antibodies against RVFV (ELISA, IgG and/or IgM) - without any clinical suspicions reported by the public and private veterinary services. A retrospective study was then conducted in 2008, using blood samples collected from clinically suspected human cases of dengue or chikungunya illness who had tested negative for these two diseases, between 1 September 2007 and 31 May 2008. Ten human RVF cases were 
found (including IgM- and/or RT-PCR-positive samples), seven of them (70\%) occurring from January to April, during the hot, rainy season [5]. This study has

\section{FIGURE 2}

Geographical distribution of Rift Valley fever

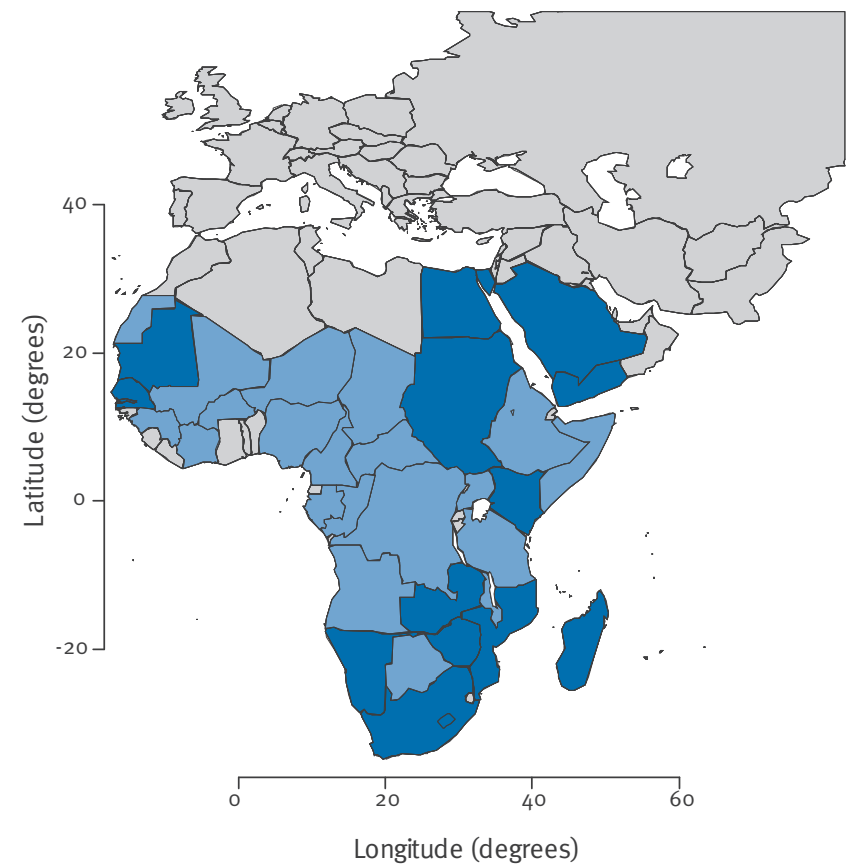

$$
\begin{aligned}
& \square \text { RVF free (or unreported) } \\
& \text { Outbreaks and epidemics } \\
& \square \text { Sporadic cases and serological evidences }
\end{aligned}
$$

demonstrated that RVF had been circulating in Mayotte at least since early 2007 , probably introduced there by the illegal importation of live infected ruminants from other Comoros islands.

In 2008, a RVF epidemic occurred in Madagascar with over 500 human cases [43]. Several outbreaks were reported in South Africa in late 2007 and 2008 without any reported human cases [44].

\section{Factors of change}

Factors that could cause a change in the epidemiology of RVF are summarised in Table 3. Irrigated areas, including rice fields, constitute favourable breeding sites for many mosquito species. Dambos are temporary surface water bodies found in semi-arid eastern Africa. With heavy rainfall and consecutive flooding, considerable mosquito proliferation may occur (mostly Aedes and Culex spp.). Wadi are temporary rivers encountered in arid areas (e.g. Yemen or Saudi Arabia): when they stop flowing, surface water remains available in ponds and mosquitoes may proliferate.

\section{Livestock trade and the Mediterranean region} Livestock trade and transport may affect the geographical distribution of RVF and contribute to a large scale - sometimes continental - spread of the disease and to the introduction of the virus into disease-free areas via livestock movements. RVF cases were reported in irrigated areas of the Sudan during the 1970s. Antibodies were detected in camels that crossed the border from Sudan to Egypt, suggesting that infected camels may have introduced RVFV into Egypt [39].

Source: United States Centers of Disease Control and Prevention [38*].

\begin{tabular}{|c|c|c|c|c|c|}
\hline Year & Country & Ecosystem & Vector & Hosts & Triggering factor \\
\hline 1975 & South Africa & $?$ & $?$ & $?$ & $?$ \\
\hline 1976 & Sudan & Irrigated area & $?$ & Small ruminants & Irrigation (?) \\
\hline 1987 & Mauritania, Senegal & Irrigated area & Culex pipiens & $\begin{array}{c}\text { Small ruminants, cattle, } \\
\text { camels, humans }\end{array}$ & $?$ \\
\hline 1993 & Egypt & Irrigated area & $?$ & Small ruminants, humans & Irrigation \\
\hline 1997 & Egypt & Irrigated area & $?$ & Small ruminants, humans & Irrigation \\
\hline $1997-1998$ & Kenya & Dambos & $\begin{array}{c}\text { Aedes spp. } \\
\text { Culexzombaensis }\end{array}$ & Small ruminants & Rainfall \\
\hline 2000 & Yemen, Saudi Arabia & Wadi & $\begin{array}{c}\text { Aedes vexans } \\
\text { Culex tritaeniorhynchus }\end{array}$ & $\begin{array}{l}\text { Small ruminants, cattle, } \\
\text { camels, humans }\end{array}$ & Rainfall and virus introduction \\
\hline $2006-2007$ & $\begin{array}{c}\text { Kenya, Tanzania, } \\
\text { Somalia }\end{array}$ & Dambos & $?$ & $\begin{array}{l}\text { Small ruminants, cattle, } \\
\text { humans }\end{array}$ & Rainfall \\
\hline 2007 & Sudan & Irrigated area & $?$ & $\begin{array}{c}\text { Small ruminants, cattle, } \\
\text { humans }\end{array}$ & $?$ \\
\hline $2007-2008$ & Mayotte & Island & $?$ & $\begin{array}{c}\text { Small ruminants, cattle, } \\
\text { humans }\end{array}$ & Virus introduction \\
\hline 2008 & Madagascar & $\begin{array}{l}\text { Rice field in } \\
\text { highlands }\end{array}$ & $\begin{array}{c}\text { Culex? } \\
\text { Anopheles? }\end{array}$ & $\begin{array}{l}\text { Small ruminants, cattle, } \\
\text { humans }\end{array}$ & $?$ \\
\hline
\end{tabular}

TABLE 3

Main outbreaks of Rift Valley fever and factors causing them 
During the outbreak in Saudi Arabia in 2000, six viral strains of RVFV were isolated from Aedes mosquitoes. These strains were genetically close to the strain isolated in Kenya (1997-1998), suggesting that the virus was probably introduced into Saudi Arabia from the Horn of Africa by ruminants [45]. It remains unknown whether the virus has survived in Saudi Arabia since 2000. In any event, the risk of re-introduction from the Horn of Africa is high. During the period of religious festivals in Mecca, 10 to 15 million small ruminants are imported from there to Saudi Arabia.

A similar pattern in sheep trade is observed between sub-Saharan Africa and northern Africa. In the coming years, the Muslim feasts of Eid-ul-Fitr and Eid al-Adha will occur between September and November, i.e. when the activity of mosquito populations is high (end of the rainy season in Sahelian Africa) [46].

Therefore, the introduction of RVF-infected animals on the eastern and southern shores of the Mediterranean Sea is a likely event. Once introduced there, RVFV may find ruminant hosts, as well as competent mosquito species [47]. However, because livestock trade from northern Africa and the Middle East to Europe is forbidden, the introduction of RVF-infected animals to Europe looks unlikely [48].

\section{Climate}

Climate warming is likely to have an impact on the geographical distribution of RVF. Higher temperatures increase mosquito feeding frequency and egg production and decrease the duration of their development cycle, as well as the extrinsic incubation period of RVFV in mosquitoes. Therefore, higher temperatures associated with increased rainfall may result in higher vector densities and vector competence and, subsequently, a higher RVFV transmission rate. In addition, transovarian transmission processes could be altered.

If the virus were introduced to northern Africa or southern Europe, mosquitoes such as Ae. vexans could play a role as vectors in many Mediterranean countries. Several Ochlerotatus species, which breed in wetlands, might also be able to transmit the virus. Culex pipiens, a ubiquitous species, is locally abundant (in wetlands, rice fields, irrigated crops, sewers etc) and may act as an amplifier in the biological cycle. Increased temperatures could also have an impact on the vector competence and capacity of other endemic European mosquito species [49], although this is difficult to quantify (it has already been proved in controlled conditions with other arboviruses). Indeed, if introduced, several potential vector species that have so far not been investigated may become involved in the transmission of the RVFV.

In East Africa, RVFV causes major epidemics at irregular intervals of 5-15 years. Climate models for this region predict an increase in the mean annual rainfall as well as an increase in the frequency and intensity of extreme rainfall events [50]. These changes may induce more severe and more frequent outbreaks in East Africa, which would thus represent a high risk area for neighbouring regions with livestock trade relationships such as the Indian Ocean islands.

\section{Vectors}

The flight capacities of Aedes and Culex mosquitoes are somewhat limited, ranging from a few hundred meters to more than $10 \mathrm{~km}[51,52]$. However, these distances are long enough to allow a local spread of RVF.

Wind transportation of infected mosquitoes has been reported for other arboviruses [53,54]. Presently, no information is available for RVFV vectors. Passive transportation of infected mosquitoes in boats or planes travelling from Africa has been reported for Anopheles mosquitoes infected by Plasmodium parasites [55]. However, for RVFV to be introduced this way, such infected mosquitoes would need to find susceptible hosts to initiate a local cycle. This event looks unlikely.

\section{Predictive models}

Risk mapping

East Africa (Kenya)

In Kenya, a correlation has been demonstrated between heavy rainfall events and the occurrence of RVF outbreaks. Maps of remotely sensed rainfall as well as vegetation index maps have been used together with ground data to monitor and predict vector population dynamics and RVFV activity and have established a correlation between these two parameters. The main advantage of remote sensing for the prediction of RVF occurrence in East Africa is the relatively low cost. It is readily available on a country and regional basis and its use may allow preventive measures to be taken such as the vaccination of susceptible livestock and the control of mosquito larvae $[56,57]$.

Predictive models have been improved over the past decade through the addition of Pacific and Indian Ocean surface temperature anomalies and rainfall and normalised difference vegetation index (NDVI) data. An accuracy of $95-100 \%$ was estimated for the prediction of Kenyan epizootics of RVF, with a lead time of two to five months [57]. The FAO has used the technology to warn countries facing an increased risk of RVF. However, the geographic scope of these models is limited because ecological and epidemiological processes are different in other areas of Africa [58]. The outlook for the use of these models is even worse for the Mediterranean basin and Europe where climate determinants differ significantly from those of East Africa and the potential ecological and epidemiological processes are unknown as the disease has never been reported in these areas.

West Africa (Senegal)

RVF is endemic in the Ferlo area (northern Senegal) [59]. This area is characterised by a temporary pond ecosystem. These ponds are filled at the beginning 
of the rainy season (July) and dry up from October to January, according to their size and the intensity of rainfall, and are favourable environment to the development of Aedes mosquito populations.
However, the East African model can not be applied in West Africa: abundant rainfall is not often associated with RVF outbreaks. The epidemiological process leading to RVF epidemics looks much more complex,

\section{TABLE 4}

Competent mosquito vectors of Rift Valley fever virus with known distribution in the European Union and candidate countries

\begin{tabular}{|c|c|c|c|c|c|}
\hline Country & Aedes vexans vexans & Ochlerotatus caspius & Culex theileri & Culex pipiens & Culex perexiguus \\
\hline Austria & $x$ & $x$ & ? & $x$ & $?$ \\
\hline Belgium & $x$ & $x$ & $?$ & $x$ & $?$ \\
\hline Bulgaria & $x$ & $x$ & $x$ & $x$ & $x$ \\
\hline Croatia $^{1}$ & $x$ & $x$ & $?$ & $x$ & $?$ \\
\hline Cyprus & $?$ & $x$ & $?$ & $x$ & $?$ \\
\hline Czech Republic & $x$ & $x$ & $?$ & $x$ & $?$ \\
\hline Denmark & $x$ & $x$ & $?$ & $x$ & $?$ \\
\hline Estonia & $x$ & $x$ & $?$ & $x$ & $?$ \\
\hline Finland & $x$ & $x$ & $?$ & $x$ & $?$ \\
\hline France (mainland) & $x$ & $x$ & $x$ & $x$ & $?$ \\
\hline France (Corsica) & $x$ & $x$ & $x$ & $x$ & $?$ \\
\hline Germany & $x$ & $x$ & $?$ & $x$ & $?$ \\
\hline Greece & $x$ & $x$ & $x$ & $x$ & $x$ \\
\hline Hungary & $x$ & $x$ & $x$ & $x$ & $?$ \\
\hline Ireland & $?$ & $x$ & $?$ & $x$ & $?$ \\
\hline Italy (mainland) & $x$ & $x$ & $x$ & $x$ & $x$ \\
\hline Italy (Sardinia) & $x$ & $x$ & $x$ & $x$ & $?$ \\
\hline Italy (Sicily) & $x$ & $x$ & $x$ & $x$ & $x$ \\
\hline Latvia & $x$ & $x$ & $?$ & $\mathrm{x}$ & $?$ \\
\hline Lithuania & $x$ & $x$ & $?$ & $x$ & $?$ \\
\hline Luxembourg & $?$ & $?$ & $?$ & $?$ & $?$ \\
\hline Former Yugoslav Republic of Macedonia ${ }^{1}$ & $x$ & $x$ & $x$ & $x$ & $x$ \\
\hline Malta & $?$ & $x$ & $?$ & $x$ & $?$ \\
\hline The Netherlands & $x$ & $?$ & $?$ & $x$ & $?$ \\
\hline Poland & $x$ & $x$ & $?$ & $x$ & $?$ \\
\hline Portugal & $x$ & $x$ & $x$ & $x$ & $x$ \\
\hline Romania & $x$ & $x$ & $x$ & $x$ & $?$ \\
\hline Slovakia & $x$ & $x$ & $x$ & $x$ & $?$ \\
\hline Slovenia & $x$ & $x$ & $?$ & $x$ & $?$ \\
\hline Spain (mainland) & $x$ & $x$ & $x$ & $x$ & $x$ \\
\hline Spain (Balearic Islands) & $x$ & $?$ & $?$ & $x$ & $?$ \\
\hline Sweden & $x$ & $x$ & $?$ & $x$ & $?$ \\
\hline Turkey $^{1}$ & $x$ & $x$ & $x$ & $x$ & $x$ \\
\hline United Kingdom & $x$ & $x$ & $?$ & $x$ & $?$ \\
\hline
\end{tabular}

$\mathrm{X}$ : vector present; ?: unknown to the authors, or not found yet.

${ }^{1} \mathrm{EU}$ candidate country.

Adapted from [1]. 
involving the joint dynamics of hosts movements (transhumance), host immunity, and a vector population with brief activity during the rainy season.

In this region, the risk of transmission was shown to be heterogeneous and linked to pond type [59]. A very high spatial resolution remote sensing image was used to characterise the temporary ponds and their environment and derive indices linked to mosquito biology [6o]. However, this work is not advanced enough to be used in surveillance programmes.

\section{Risk analysis for Europe}

A detailed, qualitative risk analysis was performed in 2005 by The European Food Safety Authority (EFSA) [1]. The main conclusions of this study are summarised below.

\section{Ruminant importations}

The importation of infected ruminants is the greatest hazard for RVF introduction to the European Union (EU). Clinical signs may not be observed rapidly in livestock living in remote, humid areas such as the Camargue region in France or the Danube delta in Romania. Such a scenario would allow RVFV to amplify and endemic foci to develop, if suitable ecological and entomological conditions were met [1].

Official RVF-free status is required for a country to export livestock and livestock meat to the EU. Such a status depends on a country's ability - relying on observable evidences - to implement an efficient disease surveillance system and willingness to report possible RVF outbreaks. These constraints are the same as for foot-and-mouth disease and other epizootic diseases. They were instituted in 1972 (directive 72/462/ CEE [61], later modified to be more stringent). The practical consequence is that any introduction of live ruminants and their products from Africa and the Middle East to the European Union is forbidden. However, illegal and unknown ruminant importations probably occur between the Middle East and central Europe, and between northern Africa and southern Europe. This is also a major component of the risk of introduction of many other important animal and zoonotic diseases, like peste des petits ruminants, foot-and-mouth disease, bluetongue disease, Crimean-Congo haemorrhagic fever, etc. For instance, a risk analysis has recently been conducted to assess the risk of introduction of peste des petits ruminants virus (a Morbillivirus) from Maghreb to France. The conclusion was that the risk was extremely low, ranging from o to 2 on a scale from o (impossible event) to 9 (certain event) [48].

\section{Vectors}

Several potential RVFV vectors are present in the EU (Tables 4 and 5). Differences in climate, seasonal variations of vector and host density, and genetic drift may result in differences in vector competence (the biological suitability of the vector to transmit the pathogen) and vectorial capacity (external factors such as number and lifespan of the vector, feeding preferences of the host) compared with the situation in Africa. Nevertheless, there is almost no doubt that several of the mosquito species in the EU, e.g. CX. pipiens, would be competent vectors for RVF [62]. Moreover, the introduction and spread of new vector species represents a further risk. For example, Ae. albopictus can transmit RVFV [62-64], and many epidemiological concerns arise from this species' current distribution in Europe: Albania, Bosnia and Herzegovina, Croatia, Italy (including Sicilia and Sardinia), south eastern continental France and Corsica, limited areas of Germany (north of the Alps), Greece, Monaco, Montenegro, the Netherlands (green houses), San Marino, Slovenia, eastern Spain, southern Switzerland, and the Vatican city [65].

\section{Virus survival}

Blood, organs, fresh meat, fetal fluids and tissues as well as hides all represent a serious hazard to at-risk occupational groups (farmers, veterinarians, slaughterhouse employees, butchers, etc). The virus persists in the liver, spleen and kidneys, but rapidly disappears from meat as the $\mathrm{pH}$ decreases with meat maturation. The importance of blood, bone and offal meal products as a vehicle for RVFV has not been evaluated [4]. Milk is not considered to constitute a risk. However, due to a lack of data, transmission by ingestion of milk can not be definitively ruled out.

Accidental RVF infections have been recorded in laboratory staff handling blood and tissues from infected animals.

\section{Conclusion}

Several national and Commission-supported analyses have been conducted to assess the risk of the introduction and spread of RVF within the EU. The conclusions have been that the overall risk was low. However, the recent reappearance of RVF in East Africa, including Sudan, the Nile Valley, and the Indian Ocean, has shown that the RVFV is very active and sensitive to climate and other environmental as well as socio-economic changes. These changes, together with growing human populations and an associated increased demand for meat, will promote greater controlled and uncontrolled movements of livestock. Consequently, the Mediterranean basin, central Europe, and the Middle East will probably be increasingly exposed to the risk of introduction of RVF. It is important to promote risk analyses that rely on accurate estimations of livestock movements between endemic and RVFfree areas. Moreover, high-risk ecosystems should be catalogued and the data updated on a regular basis to account for environmental changes. This latter activity has been initiated under the EU-funded Emerging Diseases in a changing European eNvironment (EDEN) project and should be continued once the project ends in 2010. Research programmes are needed to better characterise the bionomics of RVFV vectors in Europe and to develop RVFV introduction, installation, and 
spread models to improve disease surveillance and provide more efficient decision-making tools.

Furthermore, more efficient vector and disease control methods are needed to enable the implementation of efficient contingency plans:

- For vector control, a systematic assessment of existing methods and tools should be undertaken (laboratory and field experiments) and research programmes developing new technologies should be supported, including options for the development of genetically modified mosquitoes designed either to reduce population sizes or to replace existing populations with vectors unable to transmit the disease.

- For disease control in European ruminants, the existing vaccines should be tested, preferably in collaboration with pharmaceutical companies. Because the cheapest and most efficacious existing vaccine (the Smithburn RVFV strain) has residual pathogenic effects in ruminants and humans, research on new-generation vaccines (e.g. recombinant, or reverse-genetic vaccines) should also be supported, both for human and animal populations.

- Because a large-scale RVF epidemic appears unlikely in Europe (where a low proportion of people have direct contact with ruminants and their body fluids), human vaccination should target the population subgroups at high risk of exposure (farmers, veterinarians, slaughterhouse employees, butchers etc), once human vaccines have been developed.

- Finally, the most relevant long term strategy is to control RVF where it is endemic. A substantial effort is needed to better understand the bio-ecology of RVFV vectors and viruses and epidemiological processes in Africa, to develop predictive and quantitative risk models and maps, and to implement risk-based surveillance and control methods.

\section{Acknowledgements}

This review was conducted in the framework of the European Centre for Disease Prevention and Control funded V-borne project "Assessment of the magnitude and impact of vector-borne diseases in Europe", tender no. 0J/2007/04/13$\mathrm{PROC} / 2007 / 003$. It was compiled, edited and reviewed using EDEN and Arbozoonet funding, (EU grant GOCE-2003-010284 EDEN; EU grant agreement 211757). The paper is catalogued by the EDEN steering committee as EDEN0197 (http://www. eden-fp6project.net/). The contents of this publication are the responsibility of the authors and do not necessarily reflect the views of either the European Centre for Disease Prevention and Control or the European Commission.

* Erratum: This reference was corrected on 18 March.

\section{References}

1. European Food Safety Authority (EFSA). Opinion of the Scientific Panel on Animal Health and Welfare (AHAW) on a request from the Commission related to "The Risk of a Rift Valley Fever Incursion and its Persistence within the Community". EFSA-Q-2004-050. The EFSA Journal. 2005;3(10):1-128. Available from: http://www.efsa.europa.eu/ fr/efsajournal/doc/238.pdf
2. Meegan JM, Hoogstraal H, Moussa MI. An epizootic of Rift Valley fever in Egypt in 1977. Vet Rec. 1979;105(6):124-125.

3. Jouan A, Le Guenno B, Digoutte JP, Philippe B, Riou O, Adam F. An RVF epidemic in southern Mauritania. Ann Inst Pasteur Virol. 1988;139(3):307-308.

4. World Health Organization (WHO). Rift Valley fever in Sudan--Update 4. Available from: http://www.who.int/csr/ don/2007_11_05/

5. Sissoko D, Giry C, Gabrie P, Tarantola A, Pettinelli F, Collet L et al. Rift Valley fever, Mayotte, 2007-2008. Emerg Infect Dis. 2009;15(4):568-70.

6. Lefèvre PC, Blancou J, Chermette R. Principales maladies infectieuses et parasitaires du bétail. Europe et régions chaudes. Vol. 1. Lavoisier, editor. Généralités. Maladies virales. Londres, Paris, New York; 2003. [French].

7. Mc Intosh BM, Jupp PG. Epidemiological aspects of Rift Valley fever in South Africa with reference to vectors. Contrib Epidemiol Biostat. 1981;3:92-9.

8. Linthicum KJ, Davis FG, Kairo A, Bailey, CL. Rift Valley fever virus (family Bunyaviridae, genus Phlebovirus). Isolations from Diptera collected during an inter-epizootic period in Kenya. J Hyg (Lond). 1985;95(1):197-209.

9. Davies FG, Martin V. Recognizing Rift Valley fever. Vet Ital. 2006; 42(1):31-53.

10. Gerdes GH. Rift Valley fever. Rev Sci Tech. 2004;23(2):613-23.

11. Arishi HM, Aqeel AY, Al Hazmi MM. Vertical transmission of fatal Rift Valley fever in a newborn. Ann Trop Pediatr. 2006;26(3):251-3.

12. Gora D, Yaya T, Jocelyn T, Didier F, Maoulouth D, Amadou S et al. The potential role of rodents in the enzootic cycle of Rift Valley fever virus in Senegal. Microbes infect. 2000;2(4):343-6.

13. Weinbren MP, Masson PJ. Rift Valley fever in a wild field rat (Arvicanthis abyssinicus): a possible natural host. S Afr Med J. 1957;31(18):427-30.

14. Youssef BZ, Donia HA. The potential role of rattus rattus in enzootic cycle of Rift Valley Fever in Egypt 2-application of reverse transcriptase polymerase chain reaction (RT-PCR) in blood samples of Rattus rattus. J Egypt Public Health Assoc. 2002; 77(1-2):133-41.

15. Pretorius A, Oelofsen MJ, Smith MS, van der Ryst E. Rift Valley fever virus: a seroepidemiologic study of small terrestrial vertebrates in South Africa. Am J Trop Med Hyg. 1997; 57(6):693-8.

16. Oelofsen M.J., Van der Ryst E. Could bats act as reservoir hosts for Rift Valley fever virus? Onderstepoort J Vet Res. 1999;66(1):51-4.

17. Evans A, Gakuya F, Paweska IT, Rostal M, Akoolo L, Van Vuren PJ et al. Prevalence of antibodies against Rift Valley fever virus in Kenyan wildlife. Epidemiol Infect. 2008;136(9):1261-9.

18. Daubney R, Hudson JR, Garnham PC. Enzootic hepatitis or Rift Valley fever: an undescribed disease of sheep, cattle and man from east Africa. J. Pathol Bacteriol. 1931;89:545-579.

19. Gubler DJ. The global emergence/resurgence of arboviral diseases as public health problems. Arch Med Res. 2002;33(4):330-42.

20. Balkhy HH, Memish ZA. Rift Valley Fever: an uninvited zoonosis in the Arabian peninsula. Int J Antimicrob Agents. 2003;21(2):153-7.

21. Sall A.A.et al. Single-tube and nested reverse transcriptasepolymerase chain reaction for detection of Rift Valley fever virus in human and animal sera. J Virol Methods. 2001; 91(1):85-92.

22. Tesh RB, Peters CJ, Meegan JM. Studies on the antigenic relationship among phleboviruses. Am J Trop Med Hyg. 1982;31(1):149-55

23. Xu F, Liu D, Nunes MR, DA Rosa AP, Tesh RB, Xiao SY. Antigenic and genetic relationships among Rift Valley fever virus and other selected members of the genus Phlebovirus (Bunyaviridae). Am J Trop Med Hyg. 2007;76(6):1194-200.

24. Paweska IT, Barnard BJ, Williams R. The use of sucroseacetone-extracted Rift Valley fever virus antigen derived from cell culture in an indirect enzyme-linked immunosorbent assay and haemagglutination-inhibition test. Onderstepoort J Vet Res. 1995;62(4):227-33.

25. Paweska JT, Smith SJ, Wright IM, Williams R, Cohen AS, Van Dijk AA et al. Indirect enzyme-linked immunosorbent assay for the detection of antibody against Rift Valley fever virus in domestic and wild ruminant sera. Onderstepoort J Vet Res. 2003;70(1):49-64.

26. Jansen van Vuren $P$, Potgieter AC, Paweska IT, van Dijk AA. Preparation and evaluation of a recombinant Rift Valley fever virus $\mathrm{N}$ protein for the detection of IgG and IgM antibodies in humans and animals by indirect ELISA. J Virol Methods. 2007;140(1-2):106-14. 
27. Fafetine JM, Tijhaar E, Paweska JT, Neves LC, Hendriks J, Swanepoel $R$ et al. Cloning and expression of Rift Valley fever virus nucleocapsid $(\mathrm{N})$ protein and evaluation of a $\mathrm{N}$-protein based indirect ELISA for the detection of specific IgG and IgM antibodies in domestic ruminants. Vet Microbiol. 2007;121(1-2):29-38.

28. Paweska JT, van Vuren PJ, Kemp A, Buss P, Bengis RG, Gakuya $F$ et al. Recombinant nucleocapsid-based ELISA for detection of IgG antibody to Rift Valley fever virus in African buffalo. Vet Microbiol. 2009;127(1-2):21-8.

29. Cêtre-Sossah C, Billecocq A, Lancelot R, Defernez C, Favre J, Bouloy M, et al. Evaluation of a commercial ELISA for the detection of antibodies to Rift Valley fever virus in sera of domestic ruminants in France. Prev Vet Med. 2009;90(1-2):146-9.

30. Geisbert TW, Jahrling PB. Exotic emerging viral diseases: progress and challenges. Nat Med. 2004;10(12 Suppl):S110-121.

31. Geering W, Davis FG, Martin V, Préparations des plans d'intervention contre la fièvre de la Vallée du Rift. Manuel FAO de Santé Animale. 2003;15. [French].

32. Shimshony A, Klopfer-Orgad U, Bali S. The influence of information flow on the veterinary policy of Rift Valley fever prevention in Israel, 1978-1979. Contributions to Epidemiology and Biostatistics. 1981; 3:159-171.

33. Muller R, Saluzzo JF, Lopez N, Dreier T, Turell M, Smith J et al. Characterization of clone 13 , a naturally attenuated avirulent isolate of Rift Valley fever virus, which is altered in the small segment. Am J Trop Med Hyg. 1995;53(4):405-11.

34. Wallace DB, Ellis CE, Espach A, Smith SJ, Greyling RR, Viljoen G). Protective immune responses induced by different recombinant vaccine regimes to Rift Valley fever. Vaccine. 2006;24(49-50:7181-9.

35. Gorchakov R, Volkova E, Yun N, Petrakova O, Linde NS, Paessler $\mathrm{S}$ et al. Comparative analysis of the alphavirus based vectors expressing Rift Valley fever virus glycoproteins. Virology. 2007;366(1):212-25.

36. Wang QH, Wang XJ, Hu S, Ge JY, Bu ZG. Study on DNA immune of envelope protein gene of Rift Valley Fever Virus. Wei Sheng Wu Xue Bao. 2007;47(4):677-81.

37. Directive $2004 / 28 /$ EC of the European Parliament and the Council of the 31 March 2004 amending Directive 2001/82/ $\mathrm{EC}$ on the Community code relating to veterinary medical products. OJ L 136. 2004 April 30. p. $58-84$. Available from: http://www.echamp.eu/fileadmin/user_upload/Regulation/ Directive_2001-82-EC _-C Consolidated_Version_.pdf

38. Centers for Disease Control and Prevention (CDC). [Internet]. Rift Valley Fever Distribution Map. Available from: http://www. cdc.gov/ncidod/dvrd/spb/mnpages/dispages/rvfmap.htm

39. Abd el-Rahim IH, el-Hakim U, Hussein M. An epizootic of Rift Valley fever in Egypt in 1997. Rev Sci Tech. 1999;18(3):741-8.

40. Ahmad K. More deaths from Rift Valley fever in Saudi Arabia and Yemen. Lancet. 2000;356(9239):1422.

41. Centers for Disease Control and Prevention (CDC). Rift Valley fever outbreak---Kenya, November 2006-January 2007. MMWR Morb Mortal Wkly Rep. 2007;56(4):73-6.

42. World Health Organization (WHO). Outbreaks of Rift Valley fever in Kenya, Somalia, and United Republic of Tanzania, December 2006-April 2007. Wkly Epidemiol Rec. 2007;82:169-80.

43. Rift Valley fever - Madagascar (02). In: ProMED-mail [online]. Boston US: International Society for Infectious Diseases; 16 July 2008. Archive number 20080716.2157. Available from: http://www.promedmail.org/pls/otn/f?p =2400:1001:4293294425104239::::F2400_P1001_BACK PAGE,F2400_P1001_ARCHIVE_NUMBER,F2400_P1001_USE ARCHIVE:1001,20080716.2157,Y

44. Rift Valley fever, buffalo-South Africa: (Mpulalanga). In: ProMED-mail [online]. Boston US: International Society for Infectious Diseases; 20 September 2009. Archive number 20090920.3297. Available from: http://www.promedmail. org/pls/otn/f?p=2400:1001:50943::::F2400_P1001_BACK PAGE,F2400_P1001_ARCHIVE_NUMBER,F2400_P1001_USE ARCHIVE:1001,20090920.3297,Y

45. Shoemaker T, Boulianne C, Vincent MJ, Pezzanite L, Al-Qahtani MM, Al-Mazrou Y et al. Genetic analysis of viruses associated with emergence of Rift Valley fever in Saudi Arabia and Yemen, 2000-01. Emerg Infect Dis. 2002;8(12):1415-20.

46. Chevalier V, de la Rocque S, Baldet T, Vial L, Roger F. Epidemiological processes involved in the emergence of vectorborne diseases: West Nile fever, Rift Valley fever, Japanese encephalitis and Crimean-Congo haemorrhagic fever. Rev Sci Tech. 2005;23(2):535-55.
47. Moutailler S, Krida G, Schaffner F, Vazeille M, Failloux AB. Potential vectors of Rift Valley fever virus in the Mediterranean region. Vector Borne Zoonotic Dis. 2008;8(6):749-53.

48. Miller M, Etter E, Dufour B, Libeau G, Lancelot, R. Analyse qualitative du risque d'introduction de la peste des petits ruminants en France. Epidémiol Santé Anim. 2009;56:217-26. [French].

49. Turell MJ. Effect of environmental temperature on the vector competence of Aedes fowleri for Rift Valley fever virus. Res Virol. 1989;140(2):147-54.

50. Intergovernmental Panel on Climate Change (IPCC). Climate change 2007: the physical basis. Contribution of working group I to the fourth assessment report of the intergovernmental panel on climate change. Solomon, S., D. Qin, M. Manning, Z. Chen, M. Marquis, K.B. Averyt et al, editors. United Kingdom and New York, Cambridge University Press;2007. Available from: http://www.ipcc.ch/publications and_data/publications_ipcc_fourth_assessment_report_wg1_ report_the_physical_science_basis.htm

51. Ba Y, Diallo D, Dia I, Diallo M. Feeding pattern of Rift Valley fever virus vectors in Senegal. Implications in the disease epidemiology. Bull Soc Pathol Exot. 2006;99(4):283-9.

52. Bogojević MS, Hengl T, Merdić E. Spatiotemporal monitoring of floodwater mosquito dispersal in Osijek, Croatia. J Am Mosq Control Assoc. 2007;23(2):99-108.

53. Kay BH, Farrow RA. Mosquito (Diptera: Culicidae) dispersal: implications for the epidemiology of Japanese and Murray Valley encephalitis viruses in Australia. J Med Entomol. 2000:37(6):797-801.

54. Chapman HF, Hughes JM, Ritchie SA, Kay BH. Population structure and dispersal of the freshwater mosquitoes Culex annulirostris and Culex palpalis (Diptera: Culicidae) in Papua New Guinea and northern Australia. J Med Entomol. 2003;40(2):165-9.

55. Guillet P, Germain M, Giacomini T, Chandre F, Akogbeto M, Faye 0 et al. Origin and prevention of airport malaria in France. Trop Med Int Health. 1998;3(9):700-5.

56. Linthicum KJ, Bailey CL, Tucker CJ, Mitchell KD, Logan TM, Davies FG et al. Application of polar-orbiting, meteorological satellite data to detect flooding of Rift Valley fever virus vector mosquito habitats in Kenya. Med Vet Entomol. 1990;4(4):433-8.

57. Linthicum KJ, Anyamba A, Tucker CJ, Kelley PW, Myers MF, Peters CJ. Climate and satellite indicators to forecast Rift Valley fever epidemics in Kenya. Science. 1999;285(5426):397-400.

58. Martin V, De Simone L, Lubroth J, Ceccato P, Chevalier V. Perspectives on using remotely sensed imagery in predictive veterinary epidemiology and global early warning systems. Geospat Health. 2007;2(1):3-14.

59. Chevalier V, Lancelot R, Thiongane Y, Sall B, Diaité A, Mondet B. Rift Valley fever in small ruminants, Senegal, 2003. Emerg Infect Dis. 2005;11(11):1693-700.

6o. Soti V, Chevalier V, Maura J, Tran AL, Etter E, Lelong C et al. Landscape characterization of Rift Valley fever risk areas using very high spatial resolution imagery: case study in the Ferlo area, Senegal. Proceedings of the GISVet Conference 20-24 august 2007. Copenhagen - Denmark.

61. Council Directive 72/462/EEC of 12 December 1972 on health and veterinary inspection problems upon importation of bovine animals and swine and fresh meat from third countries. OJ L 302. 1972 Dec 31. p. 28. Available from: http://eur-lex.europa. eu/LexUriServ/LexUriServ.do?uri=CELEX:31972Lo462:EN:HTML

62. Moutailler S, Bouloy M, Failloux AB. Short report: efficient oral infection of Culex pipiens quinquefasciatus by Rift Valley fever virus using a cotton stick support. Am J Trop Med Hyg. 2007;76(5):827-9.

63. Turell MJ, Bailey CL, Beaman JR. Vector competence of a Houston, Texas strain of Aedes albopictus for Rift Valley fever virus. J Am Mosq Control Assoc. 1988;4(1):94-6.

64. Rodhain F. Aedes albopictus: a potential problem in France. Parassitologia. 1995;37(2-3):115-9.

65. European Centre on Disease Prevention and Control (ECDC). Areas of possible establishment of Aedes albopictus (the tiger mosquito) in Europe for 2010 and 2030. In : Impacts of Europe's changing climate - 2008 indicator-based assessment, E.R.N. 4/2008, p. 155. Editor. 2008. The European Environment Agency (EEA), Copenhagen. 